\title{
Problematic Issues of Protection of Procedural Rights of the Claimant in the Implementation of Enforcement Proceedings in the Context of the Decisions of the European Court of Human Rights
}

\section{Introduction}

The result of consideration of the case in court is a court decision that has the force of law behind it and is binding on all public authorities and local governments, enterprises and institutions, organizations, officials and citizens throughout Ukraine. In cases established by international agreements, the binding nature of which has been approved by the Verkhovna Rada of Ukraine - and beyond (part one of Article 18 of the Civil Procedure Code of Ukraine) $)^{2}$.

The Law of Ukraine "On Enforcement Proceedings» (hereinafter referred to as the Law) determines the conditions and procedure for execution of court decisions and other bodies (officials) subject to enforcement in accordance with the law in case of non-execution in a voluntary manner (hereinafter - the Law) ${ }^{3}$.

1 Postgraduate Student, V. M. Koretsky Institute of State and Law of National Academy of Sciences of Ukraine, kolobov.lk1608@gmail.com, https://orcid.org/0000-00015348-430X.

2 Verkhovna Rada of Ukraine (2004) Tsyvilnyi protsesualnyi kodeks Ukrayiny. [Civil Procedure Code of Ukraine]. Retrieved from: https://zakon.rada.gov.ua/laws/ show/1618-15.

3 Verkhovna Rada of Ukraine (2016) Zakon Ukrayiny «Pro vykonavche 
Article 1 of this Law stipulates that enforcement proceedings, as the final stage of court proceedings and enforcement of decisions of other bodies (officials) - is a set of actions of bodies and officials specified in this Law aimed at enforcement of decisions of courts and other bodies (officials), which are carried out on the grounds, in the manner and within the powers defined by this Law, other regulations issued in accordance with this Law and other laws, as well as decisions that are subject to enforcement in accordance with this Law.

\section{Presentation of the main material}

Analyzing the statistics from the moment of Ukraine's independence until now, it is possible to conclude that the acute problem is the long execution or non-execution of court decisions, this applies to decisions against the state and state bodies, as well as against individuals.

There is an international reaction to the situation, as in its resolutions CM/ResDH (2008)1 and CM/ResDH (2009)159, the Committee of Ministers of Europe noted the inaction of the Ukrainian government in solving the problem of long-term enforcement or non-enforcement of court decisions in Ukraine, which are the reason for repeated appeals to the European Court of Human Rights (hereinafter - ECoHR).

Citing Hornsby v. Greece, 19 March 1997, statement №18357 / 91, $\S 40$ : «The right of recourse would be illusory if the national legal system of a Contracting Party allowed the final, binding It is difficult to imagine that Article $6 \S 1$ of the Convention for the Protection of Human Rights and Fundamental Freedoms (hereinafter referred to as the Convention) describes in detail the procedural guarantees provided to parties to civil proceedings. is fair, open and prompt - and did not provide guarantees for the execution of court decisions; the interpretation of Article 6 as relating exclusively to the right to go to court and to conduct a trial could lead to situations incompatible with the principle of the rule of law which the Contracting Parties undertook to abide by when they ratified the Convention. Thus, the enforcement of a judgment rendered by any court should be considered an integral part of the «trial» for the

provadzhennya». [Law of Ukraine "On Enforcement Proceedings]. Retrieved from: https://zakon.rada.gov.ua/laws/show/1404-19. 
purposes of the article», it is possible to obtain additional confirmation of the principles of justice, the main of which is the rule of law.

The following principle of the proceedings in expressing the connection between the right of access to a court and the binding nature of a court decision can be analyzed on the example of the decision in the case of Chuikina v. Ukraine of 13 January 2011, application № 28924 / 04, in which the ECoHR found a violation of .1 Article 6 of the Convention in connection with the deprivation of the applicant of access to court in view of the court's closure of the proceedings without resolving the merits of the applicant's claim against the public authority in connection with its liquidation, which accordingly allowed the State to avoid liability for illegal acts his body.

Article $6 \S 1$ (1) of the Convention for the Protection of Human Rights and Fundamental Freedoms guarantees everyone the right to apply to a court or to arbitration in respect of any of his civil rights and obligations; thus, this article proclaims the "right to a court», one aspect of which is the right of access, ie the right to sue in civil matters. However, this right would be illusory if the legal system of a Contracting State allowed a final judgment, which is binding, not to be enforced to the detriment of one of the parties. It is even difficult to imagine that Article 6 describes in detail the procedural guarantees provided to the parties to the dispute, namely: a fair, public and expeditious hearing, and at the same time does not provide for the enforcement of judgments. If we see in Article 6 only the proclamation of access to justice and the right to a judicial proceeding, this could give rise to situations contrary to the principle of the rule of law, which the Contracting States undertook to respect when ratifying the Convention. Therefore, for the purposes of Article 6, the enforcement of a judgment given by any court must be regarded as part of a "court» (see Romashov v. Ukraine, application № 67534/01, judgment of 27 April 2004, § 42).

In accordance with Rule 61 of the ECoHR Rules (the pilot decision procedure was introduced by the Court on 21 February 2011), ... The Court must indicate in the pilot decision the nature of the structural or systemic problem or other deficiency identified and the type of remedies , must be taken at the national level to enforce a court decision...The court may decide in the operative part of the pilot decision that cor- 
rective measures must be taken within a specified period, taking into account the nature of the necessary measures and the speed with which the problem must be resolved at the national level... ${ }^{4}$

The issue of the binding nature of judgments was addressed by the ECoHR in a «pilot» judgment in Yuriy Mykolayovych Ivanov v. Ukraine, application № 40450/04, of 15 October 2009, which required the State to introduce an effective remedy to ensure adequate and sufficient protection against non-enforcement or delay in the enforcement of judgments of a national court, for the enforcement of which it is liable in accordance with the principles established by the established case law of the European Court of Human Rights.

In this decision, the ECoHR drew attention to the problems of nonenforcement of court decisions in which the state acts as a debtor in the person of certain state bodies or enterprises, because it is very common practice to close enforcement proceedings on the grounds that the debtor has no money. As a result, the claimant is left without adequate protection of his rights, loses confidence in the court, as it makes no sense to go to court to protect their rights, if the court decision is still not enforced.

Thus, the Court notes that this case concerns an existing problem, which is constantly reminded of itself, giving rise to violations of the Convention which are most often detected by the Court in cases against Ukraine; more than half of the judgments handed down by the Court in cases against Ukraine concern the issue of long-term non-enforcement of final judgments, for which the Ukrainian authorities are responsible. The Court notes that one of the first such decisions, made in 2004, was based on facts similar to those in the present case (see Voitenko). In particular, in Voitenko's case the applicant could not receive the amount of monetary compensation awarded to him in connection with his discharge from military service for four years. In Voitenko's case, in addition to finding that there had been a violation of Article $6 \S 1$ of the Convention and Article 1 of Protocol No. 1 in respect of the delay in the payment of compensation awarded by the domestic court, the Court

4 Council of Europe (2003) Polozhennya Yevropeys'koho sudu z prav lyudyny [Regulations European Court of Human Rights]. Retrieved from: https://zakon.rada.gov.ua/ laws/show/980_067. 
also found that Ukraine's legal system did not provide an effective remedy, required by Article 13 of the Convention, which can prevent delays in the enforcement of judgments or provide compensation for damage caused by such delays.

Another example of this is the Court's decision in several cases, but with the same conclusion that the long-term non-enforcement of final decisions and the lack of effective remedies in the Ukrainian legal system remain unresolved, despite the fact that there are relevant Court decisions with clear appeals to the Government to take the necessary measures to address such issues. Application of the "pilot» solution procedure. The Court reiterates, that Article 46 of the Convention, as interpreted in the context of Article 1, imposes on the respondent - State a legal obligation to take, under the supervision of the Committee of Ministers, appropriate general and / or individual measures to protect the applicant's rights. The respondent-State must also take such measures in respect of other persons whose situation is similar to that of the applicant, in particular by resolving the problems which led the Court to such conclusions (see the judgments in the cases "Scozzari \&Giunta v. Italy» [GC], statement № 39221/98 and 41963/98, Article 249, ECoHR 2000-VIII; "Christine Goodwin v. the United Kingdom» [GC], statement №28957/95, Article 120, ECoHR 2002-VI; «Lukenda v. Slovenia», statement №23032/02, Article 94, ECoHR 2005-X; «S. and Marper v. the United Kingdom» [GC], statement № 30562/04 and 30566/04, Article 134, ECoHR 2008-...).

Over time, in its resolution of 12 May 2004 on decisions revealing the systemic problem underlying the violations, the Committee of Ministers invited the Court to «indicate in its decisions on violations of the Convention what it considers to be a systemic problem, the root cause of the violation and the root cause of the problem - in particular when it may lead to an increase in the number of appeals - in order to assist States in finding a proper solution to the problem and the Committee of Ministers to monitor the implementation of decisions» (see paragraph 37 above).

It should be noted that such issues are typical not only for the legal field of Ukraine, but also exist in other countries. An example of this is the conclusion based on the results of the decision in the case "Broniowski v. Poland» [GC], statement № 31443/95, subparagraph 189-194 
and operative part, ECoHR 2004-V, and in the case "Hutten-Czapska v. Poland» [GC], statement № 35014/97, subparagraph 231-239 and operative part, ECoHR 2006-VIII, under which, in order to ensure the effective enforcement of judgments given by the Court in such cases, the Court may apply a «pilot» decision procedure, which allows it to clearly indicate in such a judgment the existence of structural problems underlying the infringements and the specific means or measures by which the respondent-State must remedy the situation.

Following the approach developed in the case "Burdov v. Russia» (№ 2) of May 7, 2002, statement № 59498/00 (see decision in the case of Burdov, subparagraph 129-130) concerning similar issues of nonenforcement of decisions of national courts in the Russian Federation, The Court considers it appropriate to apply the procedure of a «pilot» decision in the present case, given the recurring and chronic nature of the problems underlying the violations, the large number of victims of such violations in Ukraine and the urgent need to provide them with immediate and appropriate redress at the national level.

The application of the «pilot» decision procedure in this case does not contradict, as the Government have argued, the existing division of functions between the bodies of the Convention. Although the Committee of Ministers is responsible for overseeing measures to ensure that the respondent-State fulfills its obligations under Article 46 of the Convention, the Court's task is, as defined in Article 19 of the Convention - "to ensure that the High Contracting Parties comply with their obligations under the Convention and its protocols», and the best way to accomplish this task is not necessarily to repeat the same conclusions in a number of cases (see, mutatis mutandis, decision in the case «E.G. v. Poland», statement № 504225/99, paragraph 27, of September 23, 2007).

Thus, in view of the recurring nature of the problems pointed out by the Court in the present case, it is for the Court to apply the "pilot» decision procedure in order to encourage the respondent State to deal with a large number of individual cases arising from the same structural problem. exists at the national level

Thus, in view of the recurring nature of the problems pointed out by the Court in the present case, it is for the Court to apply the «pilot» 
decision procedure in order to encourage the respondent State to deal with a large number of individual cases arising from the same structural problem exists at the national level (see mentioned decision in the case of Burdov (№2), paragraph 127). Existence of practices incompatible with the requirements of the Convention.

The court notes that in the last five years since its decisions (see, for example, the above-mentioned judgment in the case «Voitenko v. Ukraine»), where numerous similar violations of the Convention were alleged in connection with the non-enforcement or excessive length of enforcement in Ukraine of final judgments of national courts on compensation and the lack of effective domestic remedies for such violations, it has already ruled. in more than 300 such cases against Ukraine. Although there are indeed certain vulnerable groups of Ukrainian citizens who are more affected by these problems than others, and who do not necessarily belong to a certain «easily identifiable category of citizens", persons who are in the same situation as the applicant (see for comparison the above-mentioned decisions in the cases of Broniowski, p. 189, and Hutten - Czapska, p. 229). As can be seen from the Court's practice to date in such cases, any person who has obtained a final decision from a national authority for which the Ukrainian authorities are responsible, is at risk of being deprived of the benefits of such a decision under the Convention.

The Court sees no reason to disagree with the Government that the reason for the delays in the execution of final decisions of national courts is the existence of a number of different dysfunctions in the legal system of Ukraine. In particular, the Court recalls its findings under Article $6 \S 1$ of the Convention and Article 1 of Protocol No. 1 in the present case, namely that delays in the execution of judgments in the applicant's favor were caused by a combination of factors such as lack of budgetary resources and inaction of state executors and shortcomings in national legislation (see paragraph 55 of the decision). In other cases in which similar issues were raised, the applicants were unable to obtain timely payment of the court's award for failure to take certain budgetary measures by the authorities or for prohibiting the seizure and sale of state-owned or state-owned property (see, for example, the abovementioned decisions in the cases of Romashov, Dubenko and Kozachko). 
The Court notes that all the above factors were within the control of the State, which has so far failed to take steps to improve the situation, despite the Court's significant and consistent practice in dealing with such cases.

The systemic nature of the problems raised in this case is also evidenced by the fact that the Court is currently awaiting the examination of approximately 1,400 applications against Ukraine, which relate in whole or in part to such issues, and the number of such applications is constantly growing. In view of the above, the Court concludes that the violations referred to in this judgment are not related to any single case or special turn of events in this case, but are the result of shortcomings in the regulatory and administrative practice of the national authorities in enforcing national court decisions for which they are responsible. Therefore, the situation in this case should be classified as the result of a practice incompatible with the provisions of the Convention (decision in the case «Bottazzi v. Italy» [GC], statement №34884/97, p. 22, ECoHR 1999-V).

The Court notes that it risks becoming part of the Ukrainian justice system and replacing the Ukrainian authorities in resolving the issue of "adequate and sufficient compensation for non-compliance or prolonged enforcement of national court decisions... This task is incompatible with the subsidiary role of the Court... (judgment in the case of «Burmych and Others v. Ukraine», pursuant to five applications №46852 / 13, $47786 / 13,56605 / 13,54125 / 13$ and $3653 / 14$ of 9 July 2013, 16 July 2013, 8 August 201316 August 2013 and 11 December 2013, § 155).

On October 15, 2009, the Grand Chamber of the ECoHR ruled that the Government of Ukraine had not taken any measures to enforce the court decision in the case of Yuriy Mykolayovych Ivanov v. Ukraine, so the Supreme Chamber of the ECoHR ruled that Ukraine should:

a) make changes to the current legislation that would ensure the procedure for assigning adequate and sufficient compensation for non-executed court decisions at the national level (within a year)

b) to pay compensation under the decisions of the ECoHR and to reach a peaceful settlement with the applicants who applied to the Court with similar complaints to the applicant before the execution of the Court's decision (within a year) 
On November 30, 2010, the Committee of Ministers of the Council of Europe, in resolution CMRESDH (2010) 222, noted that since 2004 Ukraine had not proposed a large-scale concept for reforming its national legislation to bring it into line with the Convention. And even after the adoption of a pilot decision in the case of Yuriy Mykolayovych Ivanov against Ukraine, the Government of Ukraine did not propose either a draft law or a plan to bring its legislation in line with the Convention.

In Resolution CMResDH (2011)184 of 14 September 2011, the Committee of Ministers of the Council of Europe noted that the Ukrainian government had prepared a draft law on the implementation of the above resolutions, which was adopted in first reading by the Verkhovna Rada of Ukraine "On state guarantees regarding the execution of court decisions» (on 9 September 2011) .

However, for a long time the Government of Ukraine did not comply with the Committee of Ministers' instructions on the peaceful settlement of all individual complaints submitted to the ECtHR on this issue and did not ensure compensation for non-enforcement or delays in the execution of judgments at the national level.

On February 21, 2012 the ECtHR stated that Ukraine had not taken any action to comply with the Court's judgment in the applicant's case and had therefore resumed proceedings on complaints of prolonged non-compliance with decisions of national courts.

In resolution CM/ResDH (2012) 234 of 6 December 2012, the Committee of Ministers of the Council of Europe stated that the new Law «on State Guarantees for the Execution of Judgments» (hereinafter the Law) concerns only future judgments and does not address the applicants' problems (who have already lodged complaints with the ECtHR) and cannot reduce the influx of similar complaints in the future. Moreover, the Government of Ukraine noted that the draft amendments to the Law, which also provides guarantees for payments by court decisions that came into force before the adoption of the Law. However, the Committee of Ministers noted that as of December 2012, the pilot

5 Verkhovna Rada of Ukraine (2013) Zakon Ukrainy «Pro harantiyi derzhavy shchodo vykonannya sudovykh rishen'». [Law of Ukraine "About guarantees of the state concerning execution of court decisions»]. Retrieved from: https://zakon.rada.gov.ua/laws/ show/4901-17. 
decision in the case of Yuri Ivanov against Ukraine remains completely unfulfilled.

On October 16, 2013, the above-mentioned amendments to the law were adopted. According to these guarantees, in case of insufficiency of funds of the debtor, the amounts specified in court decisions will be automatically paid from the State budget (concerning lawsuits against the state and state bodies, organizations, etc.).

On May 26, 2015, the Ukrainian Helsinki Human Rights Union (DHDD (2015) 595) informed the Committee of Ministers that the budget of Ukraine includes an amount for compensation under ECtHR decisions, which can cover only $1 \%$ of Ukraine's debt for such payments.

The state should amend the Law of Ukraine «On State Guarantees for the Execution of Judgments» so that it covers all final decisions of national courts, not just only those adopted after the entry into force of this law.

In communication DH-DD (2015)763 of 9 July 2015, the Government of Ukraine announced the amount of compensation paid for this category of cases in 2013, 2014 and 2015, but the Committee of Ministers noted that the Government of Ukraine did not specify the amount of debt on the payment of compensation remained and what amounts are to be paid in the near future.

In April 2015, the Ukrainian government announced that it would improve the mechanism of execution of court decisions. The mechanism was that debts on payments by court decisions (both national and ECtHR), namely UAH 7,544,562,370 of debt, could be partially repaid at the expense of financial treasury bills with a maturity of up to seven years.

In this regard UHHRU (DH-DD (2015) 595) noted that this mechanism has numerous shortcomings. Namely, payments on promissory notes that are provided for 7 years, which is a very long period.

On June 10, 2015, the ECtHR Secretariat informed the Committee of Ministers that Ukraine was the most serious problem, as more than 9,000 complaints from the same issue (non-enforcement or unreasonably long execution of court decisions) are currently pending before the ECtHR.

On June 2, 2016, the Verkhovna Rada adopted the Law «On Bodies and Persons Enforcing Judicial Decisions and Decisions of Other Bodies». This law somewhat solves the problem of non-enforcement of court deci- 
sions. The provisions of this law stipulate that in case of damage caused by the state executor, this damage is compensated at the expense of the state. However, there is still no proper mechanism for such proof and compensation, this compensation applies only to the activities of state executors, and it is not clear whether the inaction of state executors to enforce a court decision on control of legality will be considered as causing harm ${ }^{6}$.

With regard to national legislation, then according to recommendations and the European Court of Justice and the Committee of Ministers, Ukraine should introduce a rule that would provide for the appointment of compensation to a person for long-term non-compliance with a court decision.

Such legal conclusions are consistent with the legal position set out in the decision of the Grand Chamber of the Supreme Court dated 05.12.2018 № 12-197gs18, according to which «By virtue of Articles 1, 5 of the Law of Ukraine "On bodies and persons carrying out enforcement of court decisions and decisions of other bodies» enforcement proceedings as the final stage of court proceedings and enforcement of court decisions and decisions of other bodies (officials) is a set of actions of certain bodies and persons aimed at enforcement of decisions and conducted on grounds, within the powers and in the manner defined by the Constitution of Ukraine, laws and regulations. Enforcement of decisions is entrusted to the bodies of the state executive service (state executors) and in the cases provided by this Law to private executors, the legal status and organization of which are established by the Law of Ukraine "On bodies and persons carrying out enforcement of court decisions and decisions of other bodies».

\section{Conclusions}

The most important element of judicial protection of rights and freedoms, in accordance with Article 55 of the Constitution of Ukraine and the legal position set out in a number of rulings of the European Court

6 Verkhovna Rada of Ukraine (2016) Zakon Ukrainy «Pro orhany ta osib, yaki zdiysnyuyut' vykonannya sudovykh rishen' ta rishen' inshykh orhaniv». [Law of Ukraine "On bodies and persons who carry out enforcement of court decisions and decisions of other bodies»]. Retrieved from: https://zakon.rada.gov.ua/laws/show/1403-19. 
of Human Rights is the enforcement of court decisions. The impossibility for the claimant to obtain the result of the execution of the decision made in his favor within a reasonable time is a violation of his right to judicial protection, enshrined in paragraph 1 of Article 6 of the Convention for the Protection of Human Rights and Fundamental Freedoms, as well as his right to respect for property, guaranteed by Article 1 of Protocol № 1 to the Convention, as repeatedly mentioned in the rulings of the European Court of Human Rights.

Unfortunately, we see that there are many appeals of Ukrainian citizens of the European Court of Human Rights related to the violation of their rights in the execution of court decisions. The rulings of the European Court of Human Rights point out the mistakes and violations of the rights and fundamental freedoms of citizens committed by both the Ministry of Justice of Ukraine and the judiciary. All this testifies to the not very high efficiency of the judicial system of the state.

The courts do not always remember, when considering appeals against the actions of officials during enforcement proceedings, that the main purpose of a court decision is the actual restoration of the violated or disputed right, which is achieved through prompt and effective execution of the judicial act.

But the main problem that leads to numerous appeals to the court regarding the violation of rights in the execution of court decisions is the rather low quality of work of both state executors of the State Executive Service of the Ministry of Justice of Ukraine and private executors of the Ministry of Justice of Ukraine.

To improve the quality of work of both the judiciary and enforcement proceedings, it is necessary to accelerate the movement on the implementation of European Union law and its experience in domestic law, and the implementation in practice of law enforcement agencies, the experience of European countries.

\section{References}

Council of Europe (2003) Polozhennya Yevropeys'koho sudu z prav lyudyny [Regulations European Court of Human Rights]. Retrieved from: https://zakon.rada.gov.ua/laws/show/980_067. 
Verkhovna Rada of Ukraine (2004) Tsyvilnyi protsesualnyi kodeks Ukrayiny. [Civil Procedure Code of Ukraine]. Retrieved from: https://zakon. rada.gov.ua/laws/show/1618-15.

Verkhovna Rada of Ukraine (2013) Zakon Ukrainy «Pro harantiyi derzhavy shchodo vykonannya sudovykh rishen'». [Law of Ukraine "About guarantees of the state concerning execution of court decisions»]. Retrieved from: https://zakon.rada.gov.ua/laws/show/490117.

Verkhovna Rada of Ukraine (2016) Zakon Ukrainy «Pro orhany ta osib, yaki zdiysnyuyut' vykonannya sudovykh rishen' ta rishen' inshykh orhaniv». [Law of Ukraine "On bodies and persons who carry out enforcement of court decisions and decisions of other bodies»]. Retrieved from: https://zakon.rada.gov.ua/laws/show/1403-19.

Verkhovna Rada of Ukraine (2016) Zakon Ukrayiny «Pro vykonavche provadzhennya». [Law of Ukraine "On Enforcement Proceedings]. Retrieved from: https://zakon.rada.gov.ua/laws/show/1404-19.

\section{Summary}

The article considers the issue of non-execution and / or long-term execution of court decisions by the judicial bodies of Ukraine, which are assigned the relevant functions by law, which serves as the basis for numerous appeals of citizens to the European Court of Human Rights. The decisions of the European Court of Human Rights on the consideration of complaints of persons who are parties to enforcement proceedings - collectors in connection with the noncompliance of the state of Ukraine with court decisions and resolutions of the Cabinet of Ministers of Europe are analyzed.

Keywords: collector, enforcement proceedings, private proceedings, access to court, pilot solution, European Court of Human Rights, Convention for the Protection of Human Rights and Fundamental Freedoms, resolution of the Committee of the Council of Europe 